DOI: 10.31866/2617-2674.4.2.2021.248680

UDC 791.1(477)"20"

\title{
THE DEVELOPMENT OF CONTEMPORARY UKRAINIAN CINEMA
}

\section{Oleksandr Bezruchko ${ }^{1 a}$, Nataliia Kachmar ${ }^{2 b}$}

${ }^{1}$ Doctor of Study of Art, Ph.D. in Cinematographic Arts, Television, Professor; e-mail: oleksandr_bezruchko@ukr.net; ORCID: 0000-0001-8360-9388

${ }_{2}^{2}$ Master's Student at the Cinema and Television Arts Department; e-mail: natalie.kaczmar@gmail.com; ORCID: 0000-0001-8444-3746

${ }^{a}$ Kyiv National University of Culture and Arts, Kyiv, Ukraine

${ }^{b}$ Kyiv University of Culture, Kyiv, Ukraine

Keywords:
cinema;
history;
development;
potential;
prospects;
directions;
film industry

For citation:

Bezruchko, O. and Kachmar, N., 2021. The Development of Contemporary Ukrainian Cinema. Bulletin of Kyiv National University of Culture and Arts. Series in Audiovisual Art and Production, 4(2), pp.208-216.

\section{Problem statement}

In recent decades, Ukrainian cinema has been growing. Films based on presenting the problems of the present, reflecting the Ukrainian identity, are ap- pearing. They are interesting for both the Ukrainian audience and the international community. Therefore, the study of the problem of formation and development of modern Ukrainian cinema is important and relevant in modern conditions. 


\section{Recent research and publications analysis}

Analysis of the modern Ukrainian cinema history, the study of the main problems of national film production has been covered by a number of scientific publications.

I. Burnashov (2015) believes that in the field of the film industry there are many problems that pull each other. In particular, he emphasizes that if we receive a low-quality film product, the reason is largely due to lack of logistics, the inexperience of film workers, involvement in the main roles of the same actors. The author also draws attention to mistakes in choosing the genre, low budget films, which cannot pay off due to the small number of cinemas.

Research in the field of material and legal support and assistance of the state for the highly productive development of cinema is reflected by $\mathrm{K}$. Koroshchenko (2020). The author proved that producing quality films is beneficial not only for the economy but also for the world perception of Ukraine as a state that is able to move forward in all areas.

The development of the Ukrainian film industry, as it is emphasized by E. Zin (2007) and S. Hnatiuk (2014), is a significant contribution to the spiritual development of the nation, as well as an opportunity for future international recognition and perception of domestic cinema as another quality product from Ukraine.

Purpose of the article is to investigate the history of contemporary Ukrainian cinema and to analyze the ways of its development. Highlight the main problems of national film production; identify the main principles and areas of its potential realization, the conditions for creating a successful and engaging film industry in Ukraine.

\section{Main research material}

According to the 'National Strategy for the Development of the Film Industry in Ukraine for 2015-2020' (2015), the creation of a successful, investment-attractive film industry in Ukraine, focused on both the domestic film market and its niche in the international cultural space, and the global audiovisual industry is one of the most important areas of state cultural policy. The state considers cinema as one of the main tools for ensuring information security of the country, patriotic and educational function of the state and building a positive image of Ukraine.

Contemporary Ukrainian cinema is experiencing rapid growth. Ukrainian films are regularly released in Ukrainian cinemas, they are shown in competitions of prestigious world film festivals, a generation of promising artists debuts with feature films, Ukrainian film companies cooperate with the state and international partners.

However, the historical review shows that at the beginning of the 21st century the situation in this area was radically different. The annual production of new Ukrainian films was insignificant, and most of them went completely unnoticed by the audience - both in Ukraine and, of course, in the world. Until the beginning of 2014, the state film market was dominated by Russian films. The long Soviet policy in this area and the transitional stage of Ukrainian formation, the difficult economic situation of the country did not provide the resource advantages of the Ukrainian producer. The war in eastern Ukraine prompted Ukrainian filmmakers to show the fighting, the heroism of the defenders of the Fatherland and life under Russian occupation. This time is characterized by the emergence of new films. There is an expansion of the genre range. Neverthe- 
less, at the same time, the theme of historical drama remains relevant (Koroshchenko, 2020, p.5).

On January 13, 1998, Verkhovna Rada of Ukraine adopted the Law of Ukraine 'On Cinematography', which provided for a number of measures to restore Ukrainian cinema as an art. Since then, there has been a gradual increase in film production in Ukraine. A new generation of artists has come to Ukrainian cinema, united around the Contemporary Ukrainian Cinema Society (SUK). Collective projects of Ukrainian directors have started to appear - 'Arabesques', 'Ukraine, Goodbye!', 'Babylon'13'. There was established a network of private (independent) film studios and private cinemas. A large number of Ukrainian films won fans among domestic and foreign viewers. These are dramatic films mostly: 'Prayer for Hetman Mazepa' (2001) by Yu. Illienko, 'Shtolnia'('Adit') (2006) by L. Kobylchuk, 'In the Fog' (2012) by S. Loznytsia, 'Guide' (2013) by O. Sanin, 'Donbass' (2018) by S. Loznytsia, etc. (Sabadash, 2019, p.174).

In January 2015, the Ukrainian State Film Agency - the central executive body, which activities are directed and coordinated by the government of Ukraine through the Minister of Culture and Information Policy of Ukraine and which implements the state policy in the field of cinema - presented a draft of the National Strategy for the Development of the Film Industry of Ukraine for 2015-2020 (2015). The strategy defines the main priorities, tasks and mechanisms of state policy in the field of cinematography, its personnel, ideological and social content, and is the basis for making changes and additions to the current legislation of Ukraine, management and financing of cinematography. The Ukrainian State
Film Agency was developing this document from August until December 2014 based on international practices, consultations with the National Union of Cinematographers, the Public Council of the Ukrainian State Film Agency, industry organizations and practitioners of the film industry.

As the then head of the Ukrainian State Film Agency P. Illienko aptly noted: 'Cinematography for the state is a strategic resource of socio-economic, cultural, spiritual and ideological development of society' (Burnashov, 2015, p.2).

Monitoring of the intensity of filmmaking showed that in 2015 eight Ukrainian films were shot and produced. The most famous of these are 'Hetman' (directed by V. Yamburskyi), 'Song of Songs' (directed by Ye. Neiman), 'On the Other Side' (directed by O. Lytvynenko). The following year Ukrainian film production increased to 21 films. 'I Am with You' (directed by 0 . Turanskyi), ' 8 Best Dates' (directed by M. Vaisberh), 'The World for the Eyes' (directed by N. Parfan) and others. 22 films were released in 2017 ('Cyborgs' directed by A. Seitablaiev, 'Another's Prayer' directed by A. Seitablaiev, 'Infogolic' directed by V. Shpakov, etc.). The largest number of films was shot in 2018. The films 'Me, You, He, She' (directed by V. Zelenskyi), 'Crazy Wedding' (directed by V. Dykyi), 'Stolen Princess' (directed by O. Malamuzh), 'Bus №13' (directed by 0 . Bezruchko) and others left a bright response in the audience. Examples of high-quality modern Ukrainian cinema in 2019 were the film-musical 'Hutsulka Ksenia' directed by Olena Demianenko, based on the operetta of the same name by Yaroslav Barnych. In 2020, despite the beginning of the coronavirus pandemic, such films as 'My Thoughts Are Silent' (directed by A. Lukich), 'Faithful' (direct- 
ed by H. Syvolap), 'Our Cats' (directed by V. Tykhyi), 'Hell's Banner, or Cossack Christmas' (directed by M. Kostrov) and others were released. One of the most famous films of that year was the drama 'Atlantis' directed by Valentyn Vasianovych, which was selected by the Ukrainian Oscar Committee as a national nominee for the Oscar in the nomination 'Best International Feature Film'. However, the film was not destined to go into the category of 'International Feature Film' and win the coveted Oscar.

As Ukrainian producer Denys Ivanov noted, 'Ukrainian cinema should be compared to other national cinemas, primarily in Europe. Back in 2017, Ukrainian cinema accounted for $1 \%$ of the total market. In 2018, this indicator was already at the level of $10 \%$, and in 2019 - about 25\%, which is quite a good indicator' (Slipchenko, 2019).

Today, the most successful producers of film products in Ukraine are 'Kvartal 95' Studio, 'TRK Ukraina', 'StarLightMedia', '1+1 media', 'Film.UA', which have created dozens of films and TV shows that are quite popular in the Ukrainian cinema space.

According to K. Koroshchenko (2020, p. 6), 'the analysis of the contemporary development of the film industry makes it possible to assert the change of basic guidelines and value vectors of development. The showing of entertaining and humorous films and shows indicates that the main task of cinema today is an entertaining function. However, modern cinema tries to raise the problems of everyday life and help in the formation of "the man of the modern era"'.

In summary, it can be noted that Ukrainian cinema has just begun to develop. I. Yu. Burnashov believes that 'there are many factors in the absence of cinema until 2014, but the main one is a large number of Russian film products. After the events in the East of the country and the change of the vector of Ukraine's development to European integration, Ukrainian cinema saw the light, and the world saw Ukrainian cinema and appreciated it at international festivals. The main task now is to build an effective mechanism of administrative and legal regulation of this area in order to develop and ensure the proper functioning of the domestic film industry' (Burnashov, 2015, p.21).

This is facilitated, despite some pessimistic stagnation in the current state of the film industry, by the existence in Ukraine a strong historical, professional, creative potential for the development of cinema, the disclosure of which will allow the country to take honourable, leading positions in filmmaking both in the EU and on the world stage.

These processes are currently taking place in difficult conditions. By comparing the experience of foreign cinema and the state and developments in the field of Ukrainian cinema in recent times, it is possible to draw parallels and highlight the problems of its development. First, it is worth noting the uncertainty of the filmmakers currently working. Despite the fact that there are statistics of genre preferences of Ukrainians, filmmakers still make mistakes when choosing a genre, but the experiment sometimes fails and a lot of money is lost.

The Law of Ukraine 'On Amendments to some Laws of Ukraine regarding Languages of Audiovisual (Electronic) Mass Media' dated May 23, 2017, played an important role in the shooting of national cinema. According to this law, three-quarters of content on national and regional channels must be Ukrainian- 
language. To address the issue of replacing Russian-language series and films, it is necessary to intensify the process of creating high-quality highly professional Ukrainian film production (2017).

According to the research of E. A. Zin, M. T. Kyiyaka and S. L. Hnatiuk the following state film studios operate in Ukraine: the Dovzhenko National Film Studio, technical capacity of which is actively leased by a number of leading Ukrainian production companies (Ukrainian Media Group, Star Media, Star Media, 'PRO-TV') and TV channels ('Inter', 'Studio ' $1+1$ '); Odesa film studio of Feature Films; Ukrtelefilm Studio, which is considered to be the best in Ukraine from a technical point of view for television shooting; National Cinematheque of Ukraine, Ukrainian Studio of Chronicle and Documentary Films, Ukrainian Film Studio of Animated Films; more than 20 non-state film studios: Illuminator service, Fresh Production Group, Patriot Rental, Filmlight Studio, Postmodern, KWA sound production, FilmUA, Camera Technologies, Filmotechnic, Kinotur, Pronto Film, InsightMedia Production Center, Starmedia, LeDoyen, CoffeePost, PostModern, Film service Kartochchi Ukraine. The represented companies provide a full range of world-class film production services, most of them have their own production facilities and developed infrastructure, necessary for quality service (Zin, 2007, p.335).

S. L. Hnatiuk (2014) notes that filming areas are growing in Ukraine today there are pavilions with a total area of over 20,000 square meters, new filming areas with a total area of at least 10,000 square meters are being built.

However, the volume of production of these film studios, according to the research of E. A. Zin, reaches $10-15 \%$ of the film production volume in 1990. Foreign products dominate the market of the TV industry. The share of Ukrainian production does not exceed five per cent. With such a redistribution, Ukrainian cinema suffers significant financial losses. The material support of film studios is technically obsolete and cannot be compared to the capabilities of foreign TV producers (Zin, 2007, p.337).

Producer Ivanna Diadiura, as stated in the online article 'What does Ukrainian cinema lack?', advises looking for problems of the Ukrainian film industry in the number of cinemas and screens in Ukraine. After all, why make movies if you have nowhere to show them? In Ukraine, there is one cinema per 200,000 citizens, which is 15 times less than in France and 10 times less than in other European countries. According to the Ukrainian State Film Agency, currently, only 76 of the 453 district centres have working cinemas. There are 2,071 stationary cinemas (630 of them working) and 92 mobile video projection complexes in 28,504 rural settlements. Even small movie budgets can't pay for themselves with a small network of cinemas.

Another problem with low-quality Ukrainian film products is the inexperience of film workers. The same actors are filmed. Even a small movie budget can't pay for itself. Mistakes in the choice of genre, underestimation or ignorance of the aesthetic needs and requests of the filmmaker are costly to Ukrainian cinema. Significant problems are also caused by the low logistics of film studios, outdated equipment. In addition, there is another problem, the essence of which lies in the moral and ethical plane of today - even if the state allocates sufficient funds for the development of cinema, there is no guarantee that the funds will go to their 
intended purpose and use them properly. Because, as a film expert, Aksinia Kurina successfully noted, 'the most important problem of the Ukrainian film market is not even the lack of money. This is the absence of a film school because if we imagine a hypothetical situation that we will fill the national cinema with money, it is very unlikely that we will get a quality product' (Koroshchenko, 2020, p.23).

Thus, the urgent problem in Ukraine is the formation of a modern national film industry, which would correspond to the international practice of organizing the film process based on highly adapted to the needs of modern legal, organizational and economic principles of its development.

Prospects in any creative field, as in any other, follow directly from past achievements, from such successes, which create a solid foundation for growth. And whether this growth will become real depends on favourable conditions. On the background of the famous achievements of the past, the outlook should look as bright as possible. It is worth mentioning only a few names inscribed in golden letters in the pantheon of the most famous artists of world cinema: Oleksandr Dovzhenko, Ivan Kavaleridze, Serhii Paradzhanov, Yurii Illienko, Leonid Osyka, Mykola Mashchenko, Kira Muratova.

During the years of independence, Ukraine has tried several times to make changes in the film industry. In particular, there was created a new executive body by the resolution of the Cabinet of Ministers of Ukraine 'On Approval of the Regulations on the Ukrainian State Film Agency' dated 17.07.2014 - the Ukrainian State Film Agency (Derzhkino), as well as laws 'On Cinematography' dated January 13, 1998, and 'On State Support to Cinematography in Ukraine' dated March 23, 2017, were passed. And with the adoption of the lat- ter modern Ukrainian cinema begins its countdown, as that law determines the forms and procedure for providing state financial support to cinematographers, details the mechanism of state participation in funding film production, determines the cultural and production criteria of the cultural test of films, introduces a scoring system - evaluation elements of national films, contains anti-piracy rules (2017).

This provides Ukrainian cinema not only with greater economic and technical opportunities for filming but also with a unique opportunity to integrate Ukrainian culture into European culture. Such approaches will also ensure the authority of our state and create a positive international image. That will testify to our openness and desire for internal growth by using the powerful potential of national culture.

K. R. Slipchenko (2019) fairly notes that 'international joint film production will promote the formation of smaller amounts of state support, guarantee timely and high-quality completion of the project, ensure "risk minimization" and expand distribution geography'.

Nevertheless, the role of state financial support for film production is difficult to overestimate. It is a sign of project reliability in international projects, and insurance guarantor against the risks of imbalances between different project participants. Thus, improving the mechanisms of state funding of cinema provides prospects for participation in international projects. Hungary is an example among Eastern European countries and the most active participant in joint film production. This country established a convenient scheme of financing: the state reimburses the costs involved in the production of the film after finishing work on it (Koroshchenko, 2020, p.105). 
Summarizing the above, it should be emphasized that in modern conditions, the successful development of the film industry in Ukraine is possible with the full assistance of the state, the formation of state policy in the field of cinema and cinema support systems close to modern European practices. It is necessary to systematize and intensify the activities of all public authorities with increased participation of administrative resources and to involve highly talented, knowledgeable professionals, people with experience in this field in order to implement promising, popular and time-consuming, successful film projects.

\section{Conclusion}

The development of Ukrainian cinema is a significant national heritage, it makes an invaluable contribution to the spiritu- al development of the people, serves as a guarantor of international recognition of Ukraine, its world perception and approval.

Ukraine has a strong historical, professional, creative potential for the development of cinema, the disclosure of which will allow the country to take honourable, leading positions in filmmaking in the EU and on the world stage.

A promising area of development and improvement of Ukrainian cinema is participation in international cooperation projects with the participation of two or more countries, which are involved in joint filmmaking, as well as its co-financing.

Successful development of the film industry in Ukraine is possible with the full assistance of the state, the formation of state policy in the field of cinema and cinema support systems close to modern European practices.

\section{REFERENCES}

Burnashov, I.Yu., 2015. Ukrainskyi kino proryv (ohliadova dovidka za materialamy presy, neopublikovanymy dokumentamy ta Internetu 2014-2015 rr.) [Ukrainian film breakthrough (review of the press, unpublished documents and the Internet 2014-2015)]. National Parliamentary Library of Ukraine, Information Center for Culture and Arts, [online] 5/5. Available at: <http://nplu.org/storage/files/Infocentr/Tematich_ogliadi/2015/2015_kino15.pdf> [Accessed 26 March 2021].

Choho brakuie ukrainskomu kino? [What does Ukrainian cinema lack?], 2016. RE:forma, [online] 08 August 2016 r. Available at: <https://rada.oporaua.org/novyny/reforma/11591-chohobrakuie-ukrainskomu-kino-reforma> [Accessed 26 March 2021].

Hnatiuk, S.L., 2014. Rozvytok vitchyznianoho televiziinoho kinovyrobnytstva: problemy ta perspektyvy [Development of domestic television film production: problems and prospects]. [online] Available at: <http://old.niss.gov.ua/Monitor/May08/14.html> [Accessed 26 March 2021].

Koroshchenko, K.R., 2020. Kinoindustriia v Ukraini: shliakh ta problemy stanovlennia [The film industry in Ukraine: the path and problems of formation]. Sumy.

Natsionalna stratehiia rozvytku kinoindustrii Ukrainy na 2015-2020 roky (proekt) [National Strategy for the Development of the Film Industry of Ukraine for 2015-2020 (draft)], 2015. Ukrainian State Film Agency, [online] 13 January 2015. Available at: <https://ips.ligazakon.net/ document/NT1201> [Accessed 26 March 2021]. 
Sabadash, Yu.S. ed., 2019. Traiektorii staloho rozvytku ukrainskoho suspilstva: osobystist $i$ kultura [Trajectories of sustainable development of Ukrainian society: personality and culture]. V International Scientific and Practical Conference. Mariupol, Ukraine, 15 November, 2019. Mariupol: Mariupolskyi derzhavnyi universytet. Ch. 1.

Slipchenko, K.R., 2019. Chomu ukraintsi (ne) dyvliatsia ukrainske kino [Why Ukrainians (do not) watch Ukrainian cinema]. Zaxid.net, [online] 21 February 2019. Available at: <https://zaxid.net/ chomu_ukrayintsi_nedivlyatsya_ukrayinske_kino_n1476157> [Accessed 26 March 2021].

Zakon Ukrainy Pro derzhavnu pidtrymku kinematohrafii v Ukraini [Law of Ukraine On State Support of Cinematography in Ukraine], 2017. Vidomosti Verkhovnoi Rady Ukrainy, 20, p.5.

Zakon Ukrainy Pro vnesennia zmin do deiakykh zakoniv Ukrainy shchodo movy audiovizualnykh (elektronnykh) zasobiv masovoi informatsii [Law of Ukraine On Amendments to Certain Laws of Ukraine Concerning the Language of Audiovisual (Electronic) Mass Media], 2017. Vidomosti Verkhovnoi Rady, 26, p.10.

Zin, E.A., 2007. Rehionalna ekonomika [Regional economy]. Kyiv: Profesional.

\title{
РОЗВИТОК СУЧАСНОГО УКРАЇНСЬКОГО КІНОМИСТЕЦТВА
}

\section{Олександр Безручко ${ }^{1 a}$, Наталія Качмар²b}

\author{
${ }^{1}$ доктор мистецтвознавства, професор; \\ e-mail: oleksandr_bezruchko@ukr.net; ORCID: 0000-0001-8360-9388 \\ 2 магістрант кафедри кіно-, телемистецтва; \\ e-mail: natalie.kaczmar@gmail.com; ORCID: 0000-0001-8444-3746 \\ а Київський національний університет культури і мистецтв, Київ, Україна

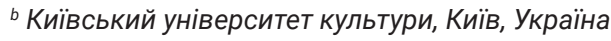

\begin{abstract}
Анотація
Мета дослідження - дослідити історію сучасного українського кінематографа, проаналізувати шляхи його розвитку; висвітлити основні проблеми становлення національного кіновиробництва, виокремити базові засади та напрями реалізації його потенціалу, умови створення успішної, інвестиційно привабливої кіноіндустрії в Україні. Методологія дослідження полягає у застосуванні таких методів: аналітичного - для вивчення і аналізу історичних матеріалів становлення українського кінематографа; емпіричного - для узагальнення моніторингу за інтенсивністю кінотворчості; теоретичного - для дослідження перспектив і напрямів реалізації національного кінопотенціалу. Наукова новизна: на основі детального та поглибленого аналізу історичного розвитку українського кінематографа, оцінки його сучасного стану вперше окреслено перспективи і напрями реалізації національного кінопотенціалу. Висновки. Аналіз сучасного стану українського кіномистецтва показав, що в національному кінематографі відбулись зміни базових орієнтирів і ціннісних векторів його розвитку, інтенсифікувались процеси реалізації його потенціалу, розпочалась побудова ефективних механізмів адміністративно-правового регулювання зазначеної сфери з метою розвитку та належного функціонування вітчизняної кіноіндустрії.
\end{abstract}

Ключові слова: кіномистецтво; історія; розвиток; потенціал; перспективи; напрями; кіногалузь 


\title{
РАЗВИТИЕ СОВРЕМЕННОГО УКРАИНСКОГО КИНОИСКУССТВА
}

\author{
Александр Безручкоa , Наталья Качмар ${ }^{2 b}$ \\ ${ }^{1}$ доктор искусствоведения, профессор; \\ e-mail: oleksandr_bezruchko@ukr.net; ORCID: 0000-0001-8360-9388 \\ ${ }^{2}$ магистрант кафедры кино-, телеискусства; \\ e-mail: natalie.kaczmar@gmail.com; ORCID: 0000-0001-8444-3746 \\ ${ }^{\text {a } К и е в с к и и ̆ ~ н а ц и о н а л ь н ы и ̆ ~ у н и в е р с и т е т ~ к у л ь т у р ы ~ и ~ и с к у с с т в, ~ К и е в, ~ У к р а и н а ~}$ \\ ${ }^{\mathrm{b}}$ Киевский университет культуры, Киев, Украина
}

\begin{abstract}
Аннотация
Цель исследования - исследовать историю современного украинского кинематографа, проанализировать пути его развития; осветить основные проблемы становления национального кинопроизводства, выделить базовые основы и направления его потенциала, условия создания успешной, инвестиционно привлекательной киноиндустрии в Украине. Методология исследования заключается в применении следующих методов: аналитического - для изучения и анализа исторических материалов становления украинского кинематографа; эмпирического - для обобщения мониторинга интенсивности кинотворчества; теоретического - для исследования перспектив и направлений реализации национального кинопотенциала. Научная новизна: на основе детального и углубленного анализа исторического развития украинского кинематографа, оценки его современного состояния впервые очерчены перспективы и направления реализации национального кинопотенциала. Выводы. Анализ современного состояния украинского киноискусства показал, что в национальном кинематографе прошли изменения базовых ориентиров и ценностных векторов его развития, интенсифицировались процессы реализации его потенциала, началось построение эффективных механизмов административно-правового регулирования данной сферы с целью развития и надлежащего функционирования отечественной киноиндустрии.
\end{abstract}

Ключевые слова: киноискусство; история; развитие; потенциал; перспективы; направления; киноотрасль 